\title{
The Contested White Lady: A Critique of New Zealand Cultural Heritage Politics
}

\author{
LINDSAY NEILL, EVELINE DUERR AND ALEXANDER TRAPEZNIK
}

$\eta$

This article places a long-term Auckland eatery, the White Lady - a pie cart established in 1948 - as an exemplar of kiwiana that, because of its mobility, currently sits outside of legislation that otherwise may recognise it as cultural heritage. This article argues that the vernacular nature of the White Lady represents yet another obstacle to its cultural heritage inclusion, reflecting the current disposition of cultural heritage in New Zealand; that it is viewed toward the elite, rather than toward the ordinary. To gain traction for the argument that the White Lady is an item of cultural heritage, a brief history of it is provided and its link to 'kiwiana' established. The legislation currently precluding the White Lady's heritage status will be identified and this article will argue that, despite its mobility, the White Lady should be considered a heritage item. In doing so, we illuminate the further consideration of other items of vernacular kiwiana culture currently excluded from heritage consideration. Such revision, exemplified by the 
White Lady's inclusion, would reflect a holistic view within New Zealand's consideration of heritage because it would include items ranging from the vernacular to the elite.

\section{The White Lady as Vernacular Kiwiana Cultural Heritage}

This section presents a brief history of Auckland's White Lady pie cart and its contested social meaning by discussing its relevance to C. Bell, ${ }^{1}$ and R. Wolfe and S. Barnett's construct of kiwiana - objects and icons in the popular imaginarycreated during the first few decades after World War Two that contribute to New Zealand national identity. ${ }^{2}$ This is important because it places the White Lady within vernacular or popular culture, themes strongly contrasting the domains of elitism currently permeating cultural heritage in New Zealand.

\section{THE WHITE LADY: A BRIEF HISTORY}

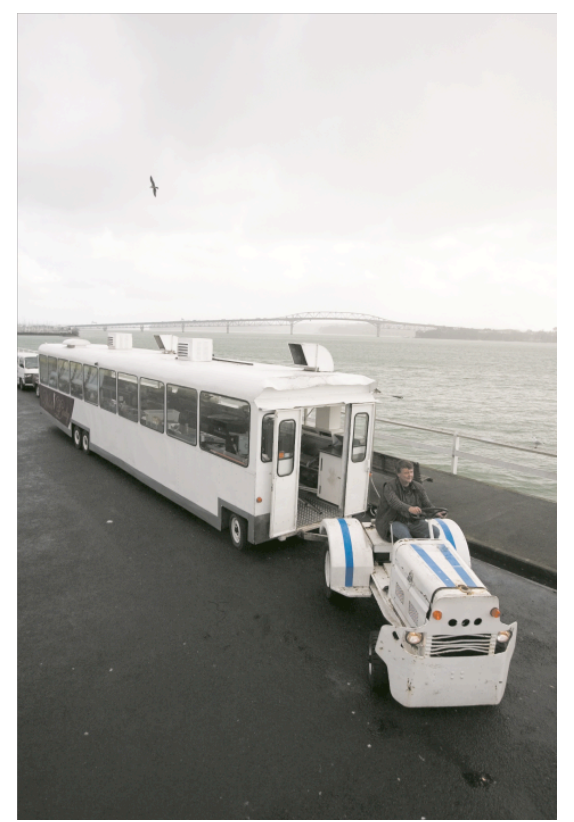

Figure 1 The White Lady ${ }^{3}$

D. McGill defines pie carts as 'caravan(s) with a [top-]hinged side door through which fast foods are dispensed, [most notably] pie pea and pud, ${ }^{4}$ mince pie with mashed potato and peas sloshed over with gravy' ${ }^{5}$ Eastern Southland Museum curator J. Geddes suggests that the caravan form of the pie cart was influenced by the rural 'stinker'. ${ }^{6}$ These were straight-sided horse-drawn wagons covered by an arched roof. 'Stinkers' were used by farm and field workers as rest huts, gaining their 
distinctive title because of the heady aroma of combined food, sweat and bucolic field work odour.

Auckland's White Lady pie cart reflects the design dynamics of the 'stinker'. The cart began trading in 1948. In a volatile industry like hospitality, its survival is a remarkable achievement. As L. Neill and others note, the average lifespan of a hospitality business in Auckland is a mere 18 months. ${ }^{7}$ Brian Alfred 'Pop' Washer started the business by selling non-alcoholic beverages at horse-racing meetings around Auckland City. Ever the entrepreneur, Pop also illegally ran a 'book'. But when racetrack authorities found this out he was banned from selling drinks at race meetings and, consequently, decided to convert the classic 'stinker'-shaped caravan into a pie cart selling food. ${ }^{8}$

Initially, Pop secured a trading space for the cart in Auckland's downtown Fort Street. At this time, Auckland City boasted a population of around 300 000, with busy electric trams along Queen Street ferrying workers and others about the town. ${ }^{9}$ As Perrott has noted, 'After the austerity of wartime rationing, including a scarcity of such feminine essentials as stockings, people could dress for a night out at the movies or the dance halls; the men in suits, the women in hats and gloves'. Dance halls were especially popular, with Auckland boasting almost 40 of them. ${ }^{10}$ Pop was quick to maximise the benefits of the post-war boom, taking advantage of the public's penchant for going out to these and other venues by offering a tasty stop-off point at the White Lady.

Pop was keenly aware of what constituted 'value for money', pricing his food around the cost of a beer. This suited the largely male clientele of the day who could relate their food experiences at the White Lady to their other indulgences, specifically the 'six o' clock swill'. ${ }^{11}$ The White Lady proved popular and it was not uncommon that customers were three-and four-deep at the counter as dance halls closed and movie theatres emptied. Pop's wife Joyce remembers how the now popular white caravan got its name:

somehow we began to refer to our business in the feminine; she was a busy night, last night, that sort of thing. Everyone talked like that, expressions like "she's a darn good car, and "I gave her the gun" were common. I named her the White Lady because she was painted white. There were no racial overtones in those days. Children were still allowed their golliwogs. ${ }^{12}$

Joyce's reminiscences also reflected how hygiene and customer expectations of it have changed since the late 1940s: 
we also had tomato sauce, bread and butter, and a glass dish of cut tomato, cucumber and onions on the counter [uncovered and for customers to help themselves to]. But no fancy serviettes. We used a communal tea towel and the customers were all happy with that. ${ }^{13}$

As time passed, the White Lady gained a positive reputation for its food and coffee. Consequently, business growth occurred and at one stage the White Lady employed sixteen people. ${ }^{14}$ In the 1950s, Auckland did not have the café culture it now boasts. However, Pop purchased and installed a Convection Goldie Tripolator that produced percolated coffee. Again, Joyce recalled that this additional offering was:

a hit. Americans staying at Auckland's top hotel of the day, the Trans-Tasman in Shortland Street, regularly visited the cart just for the coffee. They'd often remark that it was the only place [in Auckland] where you could get a decent cup of coffee. ${ }^{15}$

As well as a reputation for food and coffee, the business also developed a reputation as a social venue, a gathering point for people, many of whom considered that a night out in Auckland City was incomplete without a visit to the cart. 'Back then', Joyce remembered, 'people would head there after protest marches and parties. It was a bit of a ritual. ${ }^{16}$

Others perceived the White Lady as a barometer of Auckland's changing demography. One family of White Lady regulars used the cart as an opportunity to show their children that it offers more than just food and beverages. Neill notes that the parents often took

their four teenagers to the White Lady... as a 'cultural experience'... it's part of the city's history, and while it's changed, it's still there! The fact that the staff that night were all Asian, [shows that] the pie cart over the years has reflected the changing demographic of downtown. ${ }^{17}$

As well as serving as a barometer of demographic change, the White Lady reflects a diverse customer base. This contrasts with the restrictions that more upmarket and plutocratic dining venues provide and suggests that an egalitarian ethos has contributed toward the cart's longevity. A long-serving White Lady cook noted: 
we had everybody [as customers], everybody from sort of street workers to management. Really, the thing you saw while working at the White Lady is that there is not that much difference between those people. One might be a millionaire, and with another guy boozed to the eyeballs and a lady with a $\$ 2000$ dress and the $\$ 500$ haircut will [all] fill a spot in the gutter. ${ }^{18}$

A taxi driver who frequently drops off hungry White Lady diners noted:

when you look at the people on the pavement eating their burgers, they could be anyone from Winston Peters to a bus driver from Mangere, you know, the whole gamut. ${ }^{19}$

Peter Washer recalls how his customers have changed over time:

they'd come after the six o'clock swill. Then a surge of customers followed as the pictures got out, and then in more recent times, as nightclubs and bars have stayed open longer, we now have a surge (of customers) at 2am. I remember in the 1970s when marijuana use was big, people would arrive at the cart with the 'munchies' and eat a couple of burgers each. We had great food sales, and because everyone was mellow, very little violence. Now amphetamine-based party drugs are popular and we have noticed a big increase in water and drink sales as takers stave off dehydration. ${ }^{20}$

This broad overview of the White Lady's customers is narrowed by other research inputs. A White Lady regular and successful Auckland businessman offered:

yes I go there, not as frequently as I used to, but I would say that you could say there is a lower standard perhaps of clientele at these pie carts throughout New Zealand, but conversely at one end of the pie cart you could have someone in evening dress who has just come back from a party and down the other end you could have a couple of surfers who have been surfing all day, partying all night and decided to fill their stomachs, so there has always been a cross-section, but probably favouring the more prosaic or ordinary client. ${ }^{21}$ 
While these views reflect the White Lady's diverse client base as well as the spectrum of the demographic profile of Auckland, the White Lady has extended this by active engagement with the city's less fortunate, specifically the homeless. A cook at the cart recounted:

I remember I used to do the morning shifts on Saturday and Sundays, you know, and all the street guys, the ones that live on the street, they'd been down to Seamart, you know, the fish shop there and they had given them some fish heads and they came down to the pie cart, you know, to ask us to cook 'oh, can you please cook us something to eat?' I said, 'If Peter finds out that I am cooking fish on the grill he will kill me, give it here.' So they give me the fish heads, I boil the kettle, fill it up with hot water, salt, pepper and onions and I cook it, up, not on the grill, but in one of those stainless steel containers and after that it's cooked in about half an hour. Buttered some bread up, put it in a plastic container and 'off you go. ${ }^{22}$

This was not an isolated instance. White Lady cooks have catered in this way on other occasions, albeit they were worried that Peter Washer might object to their generosity. The cook continued:

I remember one New Year's Eve they came down [the street people], and Peter [Washer, the White Lady's owner] brought us a few drinks, and he [the street person] was telling Peter how they used to bring fish heads there and I used to cook them and used to send them away 'hurry up, go before Peter comes and don't say a word, and then he [the street person] comes and tells Peter how I always used to cook his stew! And, I say 'shhh, I told you not to say'. Even when street kids came along you know, if we made a mistake [cooked more items than ordered] we [would] keep it underneath the warmer and if anybody comes up off the street then Peter said 'just give it to them,' he was like that. ${ }^{23}$

On another occasion a worker went beyond just providing free food or a boil-up of fish heads:

some homeless people come here and one night I took one of them home when we closed the White Lady. Margarita was a noble lady... she needed a bath tub and we had a bath. $^{24}$ 
Yet despite a solid reputation for food, service and altruism the White Lady has not been without its critics, many of whom claim that the business has passed its 'sell by date' and should be consigned to 'Auckland's culinary history'. Best exemplifying this position is the Auckland City Council request that the White Lady move from its longterm trading site in Shortland Street at Queen Street, when the new Deloitte Building at 80 Queen Street was built. Multiplex, the property's developers, successfully lobbied the Council suggesting that the White Lady was an incongruous part of the 'upmarket' streetscape created by their new development. ${ }^{25}$

Despite objection from Peter Washer, the White Lady's owner, the cart was required to move to the nearby, but less central, corner of Commerce and Fort Streets, a position it still occupies. The attitude of the Multiplex developers was compounded by negative publicity that surrounded the Newmarket pie cart. This cart is the White Lady's sister business and is also operated by the Washer family.

Sue Gunn, manager of the Newmarket Business Association, which lodged a complaint on behalf of property owners and retailers [in Newmarket], said that while times had changed, the pie cart had not. It's had its day really. It's past its use-by date. We've pitched ourselves [Newmarket] in the marketplace as the premier shopping destination in New Zealand. We're like Covent Garden in London, if you like, and this does not fit. ${ }^{26}$

Yet despite a changing streetscape and claims that parts of Auckland City aspire to present themselves as being dominated by upmarket streetscapes, upper-class values and aesthetics, the city comprises a diverse socio-economic demographic. This is evidenced by the clients frequenting the White Lady. Peter Washer considers his business and its customers are unique:

my customers ignore the likes of Burger King and McDonald's to eat what they feel is truly indigenous. I like to think that we are akin to Marilyn Monroe's beauty-spot to some an indication of a malignant melanoma, to others a defining uniqueness. ${ }^{27}$

The claim that the White Lady's customers are unique is evidenced by their vocal radio talk back defence and support when the business was 
under threat of relocation from Shortland Street to Commerce Street. While their protests were in vain, and Peter Washer readily admitted that with declining patronage combined with Council pressures to move, the business could close for good, it was the media that came to the aid of the White Lady.

In 2009, Kitchen Makeover took on the challenge of rebranding and revising the White Lady's food, service and business systems in a 30minute television documentary. Palino, who presented the programme, noted early on that the White Lady could no longer rest on its laurels and introduced the realities of real business competition as a motivator for business improvement. Palino noted: 'in this day and age with all this competition it's just not good enough [the White Lady] ${ }^{28}{ }^{28}$ While owner Peter Washer found change difficult, with a new menu, service standards and control systems, he soon realised the benefit of Palino's business expertise as well as the potency of media in increasing business turnover. Consequently, after the programme aired and Peter had maximised his learning experience with Palino, he noted that the White Lady 'is now consequently trading its way out of considerable debt'. ${ }^{29}$ Shortly after this programme, Peter's longevity at the White Lady was recognised by his receiving a Life-time Achievement Award from the prestigious Lewisham Foundation.

As a result of these changes, the White Lady continues successful trading in Commerce Street. The business is now considering a move back to its prime position on Shortland Street. This possibility has occurred as both developers Multiplex and the Council came to realise that the upmarket retail business space and the White Lady 'use' of the streetscape occur at different times of the day and night. A revision and the return of the White Lady to Shortland Street will maximise public access to this area for a variety of different groups over differing time periods. Other potentials have been realised for the White Lady. It has become part of Auckland City Council's advertising campaign Big Little City. This campaign promoted Auckland City as a tourist destination using hospitality-focused themes within the city. ${ }^{30}$ Media coverage has resulted in a White Lady renaissance.

This renaissance has been further fuelled, not by the sophistication of television but rather the 'voice of the people': the Internet. Subscribers to the 2010 Lonely Planet Guide voted the White Lady, in November 2010, number 1 of 180 things to do in Auckland as well as number 1 of 870 things to do in New Zealand ${ }^{31}$. In addition to survival, the business is clearly a life marker for its customers and staff and, while the cart has attracted criticism, it has been the decisions of the public that have ultimately decided its fate. Ample opportunities have presented 
themselves that could have ended this business, yet it endures. In an ever-changing streetscape that reflects an ever-changing world, businesses like the White Lady are more than food sellers. They meld socio-economic history, personal customer/staff narratives and memories/nostalgia, contributing toward an understanding of the present though an evocation of the past. In this sense, the White Lady is a key part of New Zealand's cultural heritage as well as a unique kiwiana identifier. It is to this construct that this article now turns.

\section{KiWIANa: a CONSTRuctive Framework}

For R. Wolfe and S. Barnett kiwiana ${ }^{32}$ consists of five mass manufactured items, ${ }^{33}$ ten commercial items, ${ }^{34}$ six food-based items ${ }^{35}$ and seven objects of New Zealand's flora and fauna. ${ }^{36}$ Many kiwiana items reflect New Zealand's primary industries that have dominated commercial growth and the economy. Kiwiana has also provided cultural currency, reflecting the widespread belief that New Zealanders can 'turn their hand to anything'. This section identifies the construct of kiwiana and illustrates why the White Lady should be included within its purview. This is an important consideration for the overall aim of this article. By including the White Lady within kiwiana, the groundwork is laid for the consideration that other items of vernacular culture also require cultural heritage attention. To aid the accomplishment of this goal, a conceptual model of four items of Wolfe and Barnett's kiwiana are noted within figure 2. These items include the Buzzy Bee, Jandals, Wattie's Industries and the Swanndri.

Items of kiwiana like these include many objects of New Zealand's material culture that hold significance for New Zealanders and are often taken for granted. While Bell and Wolfe and Barnett remind us that items of kiwiana are assumed to be uniquely New Zealand, L. Neill's research reveals that many items of kiwiana have their origins in countries other than New Zealand. ${ }^{37}$

However, Wolfe and Barnett consider that the New Zealand popular cultural perception of kiwiana is that it represents symbols of nation and identity, especially for Pakeha New Zealanders who consider items of kiwiana to be iconic. ${ }^{38}$ Consequently, and despite the fact that many items of kiwiana are not indigenously New Zealand, they provide significant points of difference for New Zealanders. This is an important consideration within an increasingly cosmopolitanised and globalised world.

The four items in figure 2 have a history outside of their claim to kiwiana. The Buzzy Bee was invented in America, Jandals were adapted 


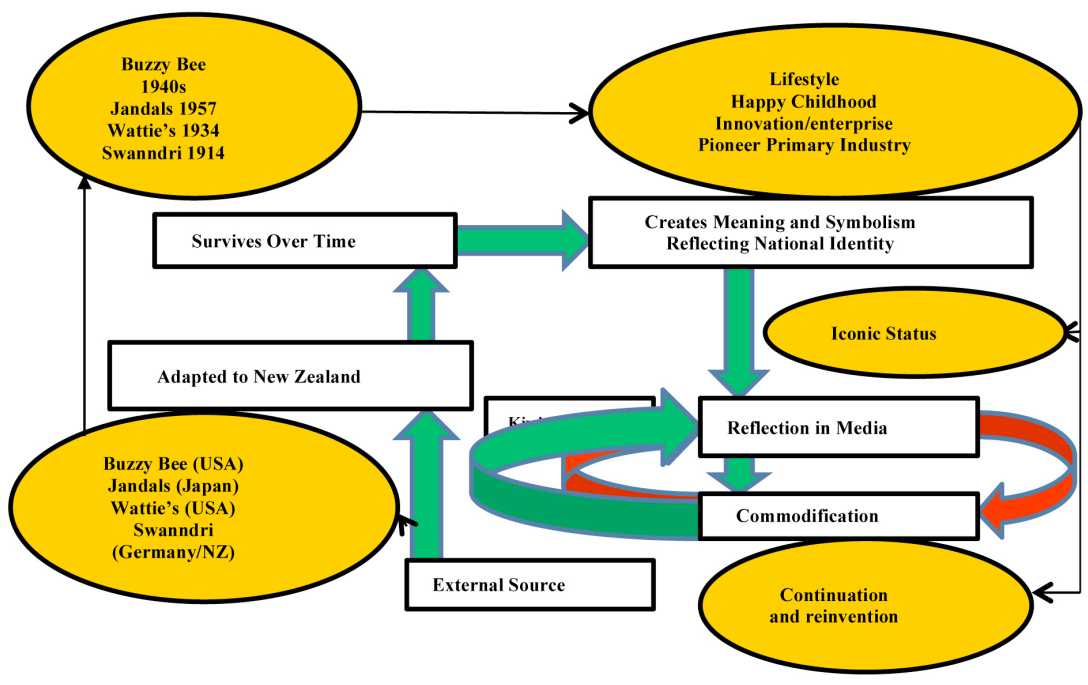

Figure: 2 Conceptual Model: The Framework of Wolf and Barnett's (2001) Kiwiana. Source: L. Neill (2012).

\begin{tabular}{|l}
\hline \\
\hline
\end{tabular}
\begin{tabular}{|l}
\hline The Evolution of Kiwiana \\
\hline
\end{tabular}

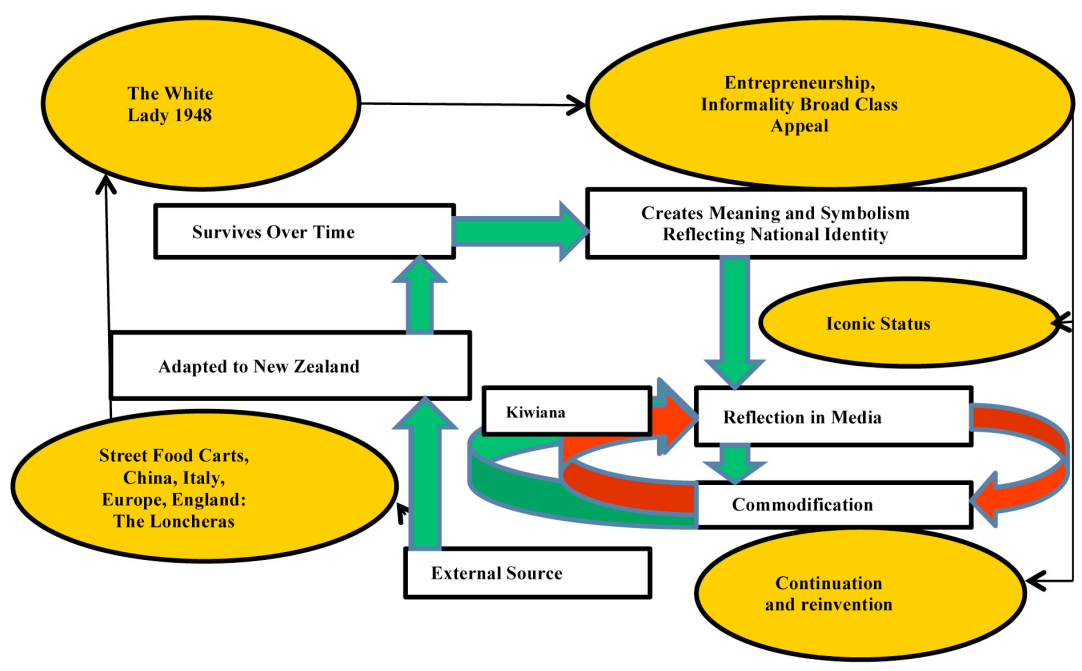

Figure 3: The White Lady as Kiwiana. Source: L. Neill (2012).

The Evolution of The White Lady.

The Interplay of Media Reinforcing the White Lady as Kiwiana. 
from Japan and Wattie's Industries were modelled on similar overseas canneries. The Swanndri, while reflecting the German loden jacket, may be the only 'true' indigenous item. These items have, according to Wolfe and Barnett, become iconic kiwiana because they respectively reflect happy and carefree childhoods, relaxed lifestyles, commercial ingenuity and the dominance of primary industry for the economy and population. ${ }^{39}$ Consequently, many Pakeha New Zealanders have, over time, taken symbolic meaning from these items that reflect constructs of identity and self. Public fascination with kiwiana has fuelled media interest in it and within wider themes of New Zealand identity, especially its symbolic forms. This has added to the commercialisation and commodification of these items as reinforcers of a New Zealand identity.

A compelling parallel exists between figure 2 and the history of the White Lady. This parallel aligns the White Lady to the construct of kiwiana and is shown in figure 3. The White Lady mirrors the constructs that analysis of Wolf and Barnett's kiwiana theme reveals. Specifically, mobile fast food street traders, like the White Lady, can be traced through the cultural histories of England, Europe, Italy and China within the research of C. Spencer, L. Civitello, L. Mason, C. Lashley and A. Morrison as well as F. Fernandez-Armesto. ${ }^{40}$ Contemporaneously, pie carts feature in the culinary history of the United States, Australia and many Spanish-speaking countries. The loncheras that are 'operated by Latina families... are in many ways similar to the pie carts' ${ }^{41}$ Pie carts became popular in New Zealand during the depression of the 1930s, gaining maximum popularity during the 1960s and 1970s. ${ }^{42}$

Congruent with Wolf and Barnett's kiwiana prescriptor, the White Lady reflects Pop Washer's entrepreneurialism, the informality of New Zealand's dining culture and cuisine and how fast food was embraced by people of various class backgrounds. The combination of longevity and recognition of the White Lady's meaning for its stakeholders clearly parallels the items in figure 2. Finally, the media has contributed to the positioning and longevity of the White Lady in a similar way that the Buzzy Bee has been 'endorsed' as iconic kiwiana by a young Prince William. ${ }^{43}$ The parallels between figures 2 and 3 are compelling evidence to support the assertion that the White Lady is an item of kiwiana.

This assertion is further supported by literature that confirms the importance of material culture - kiwiana - that S. Tannock emphasises holds potential for participant nostalgia. ${ }^{44} \mathrm{D}$. Lowenthal suggests that items evoking nostalgia act as touchstones of the past. ${ }^{45}$ These positions represent 'regimes of value ${ }^{\prime 46}$ that reflect economic and emotional 


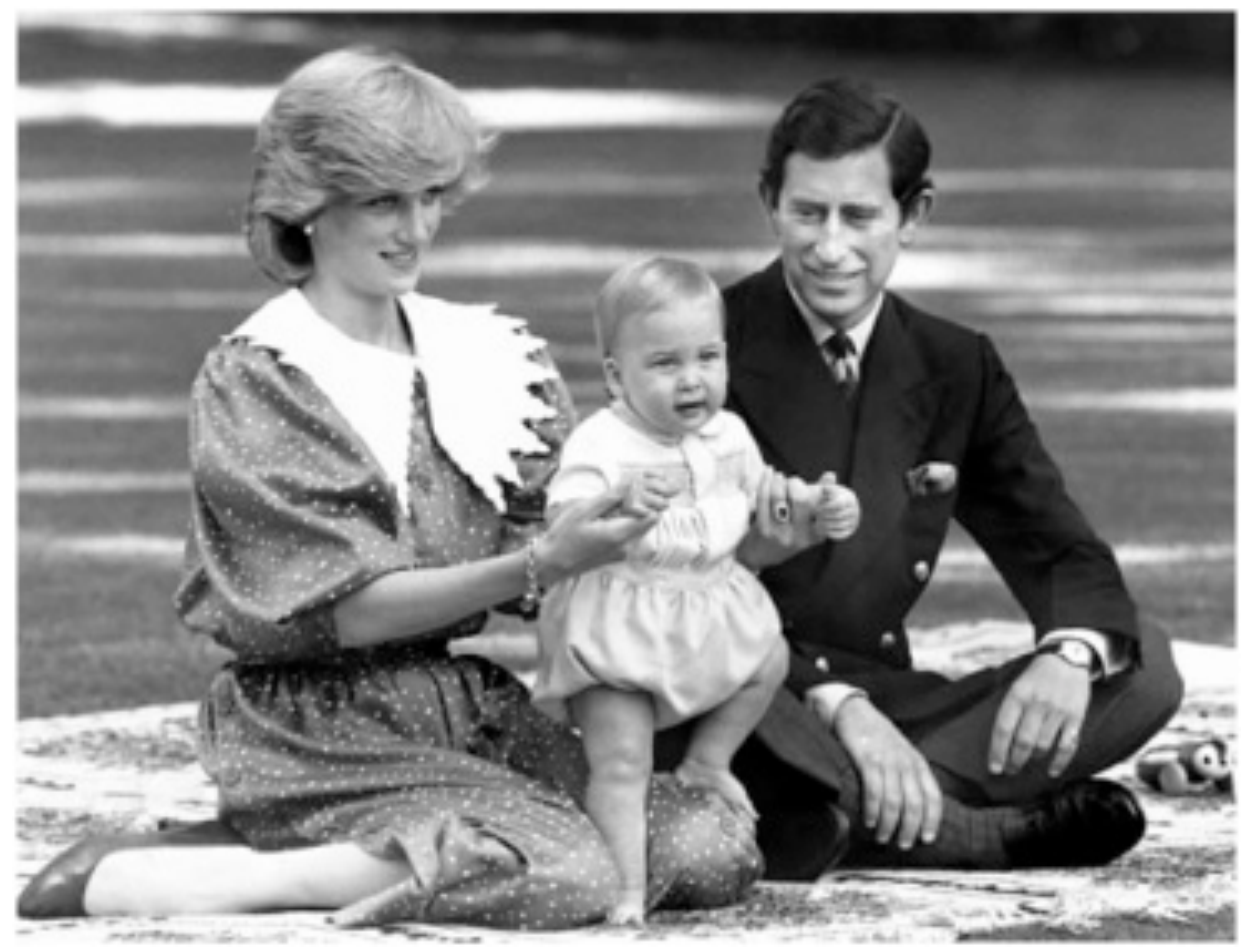

Figure 4 Prince William and his parents in Auckland with a Buzzy Bee (right), 1983 (courtsey NZ History Online)

elements that I. Woodward consequently encapsulates by suggesting that:

by studying culture as something created and lived through objects, we can better understand both social structures and larger systemic dimensions such as inequality and social difference, and also human action, emotion and meaning. Objects might be seen then, as a crucial link between the social and the economic actor, and the individual actor. ${ }^{47}$

The relationship between people and their material culture, exemplified by kiwiana, contributes an awareness of how material objects signify affinities and wider social discourses that relate to extensively held norms and values enshrined within society. ${ }^{48}$ This view supports Bell's claim that items of kiwiana enable Pakeha New Zealanders to have a sense of identity..$^{49}$ Yet, in the case of the White Lady, recognition of it as an item of kiwiana and cultural heritage remains elusive. 


\section{Cultural Heritage: An Overview}

Heritage is not about the past. Rather, it is a reflection of what exists at present. ${ }^{50}$

Cultural heritage in New Zealand is administered by local council bodies as well as central government including the Ministry of Culture and Heritage and the Historic Places Trust. These institutions embrace the definition of cultural heritage proposed by the International Council on Monuments and Sites (ICOMOS). ${ }^{51}$ This involves conservation and care of 'places of cultural heritage value'. ICOMOS defines cultural heritage as something 'possessing historical, archaeological, architectural, technological, aesthetic, scientific, spiritual, traditional or other special cultural significance, associated with human activity.$^{52}$ Within New Zealand, cultural heritage comprises:

the tangible and intangible heritage values of European, Maori and other cultural groups of New Zealand and includes, but is not limited to, buildings, places, sites, objects, archaeological remains, cultural landscapes and associated people, stories, events and memories, and wahi tapu areas [places of sacred and extreme importance to the local tribe]. ${ }^{53}$

New Zealand's cultural heritage history can be traced to the Society for the Protection of Ancient Buildings begun in England by William Morris and John Ruskin in 1877. ${ }^{54}$ As New Zealand grew as a British colony, to celebrate 50 years of settlement during the 1880s and 1890s, settlers began museums and the 'acquiring of artefacts'. ${ }^{55}$ From this came the first moves to preserve early European buildings and to collect artefacts. Maori culture was included within early heritage work. ${ }^{56}$ This began what A. Trapeznik and G. McLean suggest was a distorted view of heritage because 'heritage exaggerates and omits, candidly invents and frankly forgets and thrives on ignorance and error. ${ }^{57}$ This, coupled with the commodification / commercialisation of history further alienates it from the people who actually experience it. One key problem which leads to conflict in any assessment regarding the value of cultural heritage is the failure to recognise and reconcile the multiple values associated with specific places. Clearly, interpretations of heritage differ according to subjective positioning, discipline or methodology. This is particularly relevant to the inclusion of vernacular and kiwiana items of culture like the White Lady and its place within cultural heritage. 
It is an inescapable fact that businesses like the White Lady, just as does the average person, seldom leave behind detailed archival sources such as diaries or memoirs which would directly register their major concerns, or how they became manifest. The cheaply built structures of the poor seldom last as well as the masonry buildings of the elite. As a result, heritage built on wealth, privilege and education looms larger in the landscape than that of the commonplace. Inevitably, an unbalanced view of the past has been conserved and protected and this needs to be rectified.

\section{CULtURAL HeRItAge Legislation}

G. Vossler explains that the Historic Places Act (1993), the Resource Management Act (1991) and the Conservation Act (1987) provide for the management and protection of New Zealand's cultural heritage. Vossler posits that a duality of interest exists within cultural heritage legislation between 'the zeal and wisdom with which it is implemented, and the adequacy of the administrative and technical systems and financial resources supporting $\mathrm{it}^{\prime}{ }^{58}$ The inadequacy holds consequences for items such as the White Lady because they do not fit neatly into the categories provided by legislation: those that consider it an historic object do not protect it, while legislation that might protect it does not consider it historic.

\section{LEGISLATION AND THE WHITE LADY}

This study positions the White Lady within vernacular culture, specifically kiwiana. Vernacular culture, according to M. Lantis, is about familiarity and places: culture-as-it-is-lived.$^{59}$ In examining the application of cultural heritage legislation to the White Lady, it will become evident that the White Lady is not a comfortable fit within existing heritage structures because of its mobility and vernacular status.

Within Schedule 4 of the Protected Objects Act (1975) the categories of 'protected New Zealand objects' are noted ${ }^{60}$ The Schedule includes 'archaeological, ethnographic and historical objects of non-New Zealand origin, relating to New Zealand... Art objects including fine, decorative, and popular art... Documentary heritage objects... Nga taonga tuturu $^{61} \ldots$ national science objects... New Zealand archaeological objects... Numismatic and philatelic objects... Science, technology, industry, economy and transport objects... [and] Social history objects' ${ }^{62}$

Of these categories, the White Lady 'fits' within 'Science, technology, industry, economy and transport objects, [specifically] 8.1.(c) vehicles; related to 8.2.(a) air, land and water transport; 8.2.(c) design; 8.2.(1) the 
service and recreation industries' as well as '9.1.(c) cultural life and arts and crafts, (specifically) 9.1.(i) leisure and recreation, including all forms of sport, entertainment, and tourism... 9.1.(k) personal histories...

9.1.(m) social and political issues... 9.1.(o) urban and rural culture'. An object within the noted classifications 'is included in this category if it is: (a) not represented by at least two comparable examples permanently held in New Zealand public collections; and (b) not less than 50 years old' ${ }^{63}$ However, under section 22(5) of the Historic Places Act (1993) 'chattels or objects [must be] situated in or on that place' ${ }^{64}$ In this regard, the White Lady does not qualify for consideration as a historic place because the Historic Places Trust (HPT) considers that a historic place needs to be a fixed one. This is a contradiction in terms for a mobile fastfood facility.

While the White Lady does not meet the requirement that a historic place be in a fixed place, under section 23(2) of the Historic Places Act (1993), the Trust may assign category 1 or 2 status to any historic place, having regard to any of the following criteria:

(a) the extent to which the place reflects important or representative aspects of New Zealand history

(b) the association of the place with events, persons, or ideas of importance in New Zealand history

(c) the potential of the place to provide knowledge of New Zealand history

(d) the community association with, or public esteem for, the place

(e) the potential of the place for public education

(f) the technical accomplishment or value, or design of the place

(g) the symbolic or commemorative value of the place...

(h) the extent to which the place forms part of a wider historical and cultural complex or historical and cultural landscape.

With regard to section 23(2), a liberal translation of 'ideas' and 'cultural complex' may include contemporary themes of 'kiwiana' and vernacular culture. But this is not made explicit.

Although the Shortland Street site - or any other site - where the White Lady operated may be classified a historic place, it is the presence of the White Lady on that site that makes the site important. Because of the mobile nature of the White Lady, it would not be considered as a historic place because it has no fixed position. The Auckland City Council is reluctant to apply the provisions of the ICOMOS Charter to 
the White Lady. Discussion with the Council's heritage experts revealed that while the

Council has an interest in moveable heritage, this classification [moveable heritage is] used within archaeology and natural heritage, and that the domain of moveable cultural heritage is for museums, especially those interested in education and conservation. ${ }^{65}$

Because the White Lady is 'on the 50-year cusp', the Council perceives difficulty regarding its heritage classification. ${ }^{66}$ This compounds the legislative problems the White Lady faces in gaining heritage status. Furthermore, the Resource Management Act (1991) also has an impact on the White Lady. Under its provisions and the re-development of the White Lady's trading site the Resource Management Act necessitated the relocation of the business. This act contains a provision to allocate a 'heritage order' that would provide protective measures for the White Lady. However, because the Auckland City Council does not have a current street trading policy for businesses, including the White Lady, it would be unlikely it would administer heritage protection status to the cart given the current legal limbo.

\section{LEGISLATIVE SHORTCOMINGS AND THE WHITE LADY}

This study has established that the White Lady is not aligned to the legislation that might classify it as either a historic place or as part of wider heritage. While self-classification by the White Lady's owner as a Protected Object would protect it from export - although there is little chance of this happening - and the Resource Management Act (1991) would provide limited protection within Auckland City Council's street trading policy, this article shows that barriers exist regarding the classification of the White Lady as cultural heritage.

Clearly, a bias exists within current cultural heritage constructs that aims to identify and define rather than manufacture identity. This positions heritage recognition within a view of the past, yet cultural heritage embraces the cohesion of communities and nationhood, contributing toward a holistic identity, that this article asserts can be achieved within the contemporary streetscape ${ }^{67}$ The bias within legislation that excludes kiwiana, like the White Lady, reflects P. Hooper's concept that change is often perceived as being for a greater national good. This study suggests this position is erroneous and that vernacular heritage items like the White Lady contribute toward themes of nationhood and identity. 
Bell posits that 'kiwiana turns a blind eye to the truths of the post war period: race relations, [the] inequity of society [and] issues concerning individual rights. ${ }^{68}$ This study argues the opposite. The White Lady presents cultural heritage with an opportunity to list an item that overrides these issues. Such a listing would evoke New Zealand's mythologised egalitarianism, a construct evident throughout the White Lady's history, and in its customer and staff perceptions and narratives.

Also having a negative impact on the White Lady's status as a cultural heritage item is language. A search (using 'kiwiana' as key word) of the Ministry of Culture and Heritage web site revealed only one entry referring to 'kiwiana' - arts and crafts for the '2009 Waitangi Day Fund'. The Historic Places Trust (2010) site had no hits under the same word search, while the Auckland City Council (2010) site listed only two: an art event and a business/industry event. None of these sites had any obvious accessible alternative term offered for 'kiwiana'. This gap reinforces D. Timothy and S. Boyd's belief that 'heritage is not allinclusive: it represents some sort of legacy to be passed down to current and future generations and therefore mirrors what cultures value and choose to keep. ${ }^{\prime 69}$ Thus 'history is what a historian regards as worth recording and heritage is what contemporary society chooses to inherit and pass on. ${ }^{70}$ The recognition that cultural heritage is often built on artefacts related to wealth and not the vernacular is reinforced by Trapeznik and McLean, who argue that change is necessary within these preferences if a more balanced view of heritage is to be represented. Cultural heritage should reflect the values of all communities, not just elitist culture. N. Merriman suggests that heritage can be 'used to describe culture and landscape that are cared for by the community and passed on to the future to serve people's need for a sense of identity and belonging. ${ }^{.71}$ If this is the case, it is a potent indicator for the White Lady's inclusion.

The official inclusion of the White Lady in New Zealand's heritge will provide a starting point of balance that only a long-term functioning business, holding symbolic national identity value, can contribute. Given the paucity of hospitality business long-term survival and the White Lady's transcendence of time and social change, it has acquired outstanding survivor status by any measure. The White Lady also offers more than business longevity. It is a contemporary and historic mirror of a wider culture and society in action of the sort that Timothy and Boyd suggest 'cannot be divorced from the context of its setting ${ }^{72}$ despite changing streetscapes. For cultural heritage, the White Lady holds vernacular authenticity. 
Finally, the White Lady contradicts Timothy and Boyd's claim that 'heritage is not about the past. Rather it is a reflection of what exists at present' because it can reflect both past and present. ${ }^{73}$ Because of this uniqueness, we assert that a change in classification structures or flexibility of interpretation and mind-set are needed if items of nostalgia and 'kiwiana', such as the White Lady, are to be incorporated within New Zealand's cultural heritage. Clearly, the most obvious legislative recognition and change needs to occur within concepts of 'mobility' and 'site'. If mobile objects rather than their sites were recognised within heritage constructs, then heritage status for the White Lady would be achievable.

\section{CONCLUSION}

The purpose of this article was to critically discuss the politics and policies determining the type of artefacts that constitute cultural heritage in New Zealand. This has revealed the restrictive nature of current cultural heritage legislation regarding the recognition of vernacular items of kiwiana like the White Lady. The denial of the importance of the White Lady by concepts of cultural heritage is not mirrored within academe, where vernacular items, including the White Lady, are emphasised as symbols of national identity and narrative.

While cultural heritage is a dynamic concept, the White Lady is excluded from current listing because of its mobility and the lack of recognition that vernacular items of kiwiana have within heritage concepts. The White Lady is a potent symbol of 'kiwiana' that participants believe to be iconic. Because of this, items of 'kiwiana' like the White Lady need to be included within cultural heritage classification. Their exclusion reflects elitist cultural heritage values. This article suggests that change is necessary because iconic diners, as exemplified by the White Lady, hold an important place within New Zealand's social and culinary history and therefore wider cultural heritage.

If cultural heritage is to move away from its elitist roots and reflect the values of the 'ordinary New Zealander' then an eatery that has traded for 64 years, transcended social movement through modernism to postmodernism, gained iconic status with its stakeholders, survived in a highly competitive industry, as well as currently offering consumers hospitality, within a commercial heritage experience, must be a contender for official recognition as a significant item of cultural heritage. 


\section{ENDNOTES}

${ }^{1}$ C. Bell, Inventing New Zealand: everyday myths of pakeha identity, Penguin, Auckland, 1996, p114.

${ }^{2}$ R. Wolfe and S. Barnett, Kiwiana! The Sequel. Penguin, Auckland, 2001, pp15-30.

${ }^{3}$ A. Perrott, 'Canvas: Where have all the pie carts gone?', New Zealand Herald, 6 September 2008, p5-9.

${ }^{4}$ A meat pie topped with mashed potato (pud), and then topped with boiled and slightly mashed peas.

${ }^{5}$ D. McGill, The dinkum Kiwi dictionary, Mills Publications, Lower Hutt, 1989, p101.

${ }^{6}$ L. Neill, C. Bell and T. Bryant, The great New Zealand pie cart, Moa Becket Hachette Livre, Auckland, 2008, p143.

${ }^{7}$ L. Neill, C. Bell and N. Hemmington, 'A Pie Cart Story: “The longevity of a vernacular fast food eatery"', Locale: The Australasian-Pacific Journal of Regional Food Studies, vol 2, 2012, p105.

${ }^{8}$ Neill et al, p36.

${ }_{9}$ ibid, p37.

${ }^{10}$ ibid, p33.

${ }^{11}$ The six o'clock swill came about as workers hurried from work to the nearest pub. There, within the short space of time (from when work ended and the pub closed at $6 \mathrm{o}^{\prime} \mathrm{clock}$ ), pub patrons (in many cases) imbibed as much beer as possible. Upon leaving the pub, many patrons stopped off at the White Lady for a meal. Six o'clock closing was amended in the Sale of Liquor Act (1961), ending the six o' clock swill.

12 ibid, p37-8.

${ }^{13}$ ibid, p39.

${ }^{14}$ ibid, p43.

${ }^{15}$ ibid, p39.

${ }^{16} \mathrm{ibid}, \mathrm{p} 15$.

${ }^{17}$ L. Neill, 'The Contested "White Lady": Perceptions and Social Meanings of the "White Lady" in Auckland', MA Thesis, Auckland University of Technology, 2009, p125.

${ }^{18}$ Neill, p12.

${ }^{19}$ Neill, p117. Winston Peters is the leader of New Zealand First a coalition partner in the current New Zealand government.

${ }^{20}$ Neill, p126.

${ }^{21}$ ibid, p 116.

${ }^{22}$ ibid, p140.

${ }^{23}$ ibid, p141.

${ }^{24}$ ibid, p142.

${ }^{25}$ ibid, p117ff.

${ }^{26}$ S. Gunn, cited in D. Austen, 'Snack in the eye for snooty neighbours', The New Zealand Herald, 2000, np.

${ }^{27}$ Neill, p26.

${ }^{28}$ J. Palino (Presenter/Director), The Kitchen Job (Television Broadcast), Auckland, Television 3, 27 Januaary 2009.

${ }^{29}$ P. Washer, personal communication, 18 May 2009.

${ }^{30}$ Big Little City, 2009, 'The White Lady', retrieved 24 June 2009, from:

http://biglittlecity.co.nz/dining/item/the white lady

${ }^{31}$ Lonely Planet, 2010, 'Auckland Restaurants', retrieved 23 November 2010 from:

http:// lonelyplanet.com/new-zealand/auckland/restaurants/fast-food/white-lady

32 Kiwiana includes the everyday items of cultural significance to New Zealanders that are assumed to be uniquely New Zealand.

${ }^{33}$ The Buzzy Bee, iron roofing, Jandals, railway cups and the Swanndri.

${ }^{34}$ Bunjy jumping; rugby; sheep (farming); stamps; No. 8 wire; 'Footrot Flats'; '4 Square' shops; Taranaki gate; (All) Black; baches/ cribs.

${ }^{35}$ Watties peas; cheese (Ches and Dale); ice-cream; baking powder; Lemon and Paeroa; WeetBix.

${ }^{36}$ Grass; godwits; kiwis; paua; cabbage trees; silver ferns; pohutukawas.

${ }^{37}$ L. Neill, 'But wait there's more: you forgot the White Lady', Journal of Sociology, (in review).

${ }^{38}$ Wolfe and Barnett, pp15-30.

${ }^{39}$ ibid.

${ }^{40}$ L. Civitello, Cuisine and Culture: A History of Food and People, Wiley and Sons, Hoboken, 2004; F. Fernandez-Armesto, Near a Thousand Tables: A History of Food, Simon and Schuster, New York, 2002; FitzStephen cited in C. Spencer, British Food, Columbia University Press, New York, 2003; L. Mason, Food Culture in Great Britain, Greenwood Press, Westport, CT, 2004; and C. Lashley and A. Morrison (eds), In Search of Hospitality: Theoretical Perspectives and Debates, Elsevier Butterworth-Heinemann, Oxford, 2004. 
${ }^{41}$ Neill, Bell and Hemmington.

${ }^{42}$ ibid.

${ }^{43}$ New Zealand History online, 2012, retrieved 22 October 2012 from:

http://nzhistory.net.nz/page/prince-william-plays-buzzy-bee

${ }^{44}$ S. Tannock, 'Nostalgia Critique', Cultural Studies, vol 9, no 3, 1995, pp453-64.

${ }^{45} \mathrm{D}$. Lowenthal, The past is a foreign country, Cambridge University Press, Cambridge, 1995, p18.

${ }^{46}$ A. Appadurai, 'Introduction: commodities and the politics of value', In A. Appadurai (ed), The Social Life of Things: Commodities in Cultural Perspectives. Cambridge University Press, Melbourne, 1986

${ }^{47}$ I. Woodward, Understanding Material Culture, Sage, London, 2009.

${ }^{48}$ ibid.

${ }^{49}$ Bell.

${ }^{50}$ D. Timothy and S. Boyd, Heritage tourism, Pearson Education, Harlow, 2003, p68. ICOMOS, the International Council on Monuments and Sites, is an international nongovernmental organisation of heritage professionals engaged in the conservation of places of cultural heritage value and dedicated to the conservation of the world's historic monuments and sites: ICOMOS, 2005, np.

${ }^{52}$ ICOMOS, 2005, np.

${ }^{53}$ Coromandel Peninsula Blueprint, 2006, p4.

${ }^{54}$ G. McLean, 'Where sheep may not safely graze: A brief history of New Zealand's heritage movement 1890-2000', in A. Trapeznik (ed), Common ground: heritage and public places in New Zealand, University of Otago Press, Dunedin, 2000, pp25-44.

${ }^{55}$ ibid, p27.

${ }^{56}$ Report of the Scenery Preservation Board, 1918, p2.

${ }^{57}$ A. Trapeznik and G. McLean, 'Public history, heritage and place', in A. Trapeznik (ed), Common ground: heritage and public places in New Zealand, University of Otago Press, Dunedin, 2000, p111.

${ }^{58}$ G. Vossler, 'Sense or nonsense?: New Zealand heritage legislation in perspective', Public History Review, vol 13, 2006, p66.

${ }^{59}$ M. Lantis, 'Vernacular Culture', American Anthropologist, vol 62, no 2, 1960, pp202-16.

${ }^{60}$ Protected Objects Act (1975), New Zealand Government, Wellington, 2009, p76.

${ }^{61}$ Taonga tuturu means an object that - (a) relates to Maori culture, history, or society; and (b) was, or appears to have been, - (i) manufactured or modified in New Zealand by Maori; or (ii) brought into New Zealand by Maori; or (iii) used by Maori; and (c) is more than 50 years old': Trust Waikato, 2008, p5.

${ }_{62}^{6}$ Protected Objects Act (1975), pp76-81.

${ }_{63}^{63}$ ibid.

${ }^{64}$ Historic Places Trust, 2010.

${ }^{65}$ Personal communication, N. Short, 14 April 2010.

${ }^{66}$ ibid.

${ }^{67}$ See Bell, Lowenthal, Trapeznik and McLean and Neill.

${ }^{68}$ C. Bell, 'Kiwiana Revisited', in C. Bell and S. Matthewman (eds), Cultural Studies in Aotearoa New Zealand: identity, space and place, Oxford University Press, Melbourne, 2004, p80.

${ }^{69}$ Timothy and Boyd, p6.

${ }^{70} \mathrm{~J}$. Tunbridge and G.J. Ashworth, Dissonant heritage: the management of the past as a resource in conflict, Wiley, Chichester, 1996, p6.

${ }^{71}$ N. Merriman, Beyond the glass case, Leicester University Press, Leicester, 1991, p8.

${ }^{72}$ Timothy and Boyd, 87.

${ }^{73}$ ibid. 